\title{
Influence of Design and Application Management Information System on Performance at The Pengujan Fish Seed Center
}

\author{
Roni Kurniawan ${ }^{1}$, Abdul Jalal ${ }^{2}$, Bunga Paramita ${ }^{3}$ \\ \{ronik@umrah.ac.id, abduljalal@umrah.ac.id, bungaparamita1@umrah.ac.id $\}$ \\ ${ }^{1,2,3}$ Raja Ali Haji Maritime University
}

\begin{abstract}
The use of information systems is needed in increasing productivity in a company. The management information system is described as a pyramid building where the base layer consists of information, transaction explanations, status explanations, and so on. The Pengujan Fish Seed Center (BBI) is the Fish Seed Center of the Department of Maritime Affairs and Fisheries of the Riau Islands Province, which is located on Jalan Raya Selat, Bintan II, Pengujan Village, Teluk Bintan District, Bintan Regency. Pengujan Fish Seed Center has a fairly reliable information system as several years ago, community service was carried outand a database was designed in the form of an application that stores data on fish seed production in each cage every day during the fish harvest. This research is quantitative.The results of the data analysisfound that 1) the design variable has a partially significant effect on the Performance (Y) of the Pengujan Fish Seed Center. 2) the application of (X2) has a partially significant effect on the Performance (Y) of the Pengujan Fish Seed Center and 3) the design and application simultaneously have a significant effect on the performance of the Pengujan Fish Seed Center.
\end{abstract}

Keywords: Design, Application, Management Information System, Performance

\section{Background}

The use of information systems is needed to increase productivity, especially in a company faced with increasing competition. . For this reason, a database system is used in data management. The use of databases in acompany is mandatory to support the activities that exist within the company. A database is a collection of data that isinterconnected and can be accessed easily. With the Database Management System (DBMS), companies can easily access and store information data. Information within a company is essential to support the continued development of the company. If the information obtained is very little or the information system owned is not functioning optimallywithin a certain time the company will experience an inability to control resources, so that making strategic decisions is very difficult. Eventually, the company will experience defeat against its competitors. The Pengujan Fish Seed Center (BBI) is the Fish Seed Center of the Department of Maritime Affairs and Fisheries of the Riau Islands Province, which is located on Jalan Raya SelatBintan II, Pengujan Village, TelukBintan District, Bintan Regency. Pengujan Fish Seed Center has a fairly reliable information system as in 2018 a community service was held and a database was designed in the form of an application that stores data on fish seed production in each cage every day during the fish harvest. For this research, the researchers and the Fish Cultivation Center had an agreement in a statement of willingness to cooperate with partners 
so that both parties can find out whether the information system used is running well and performing reliably. . The research roadmap is shown in the following image:

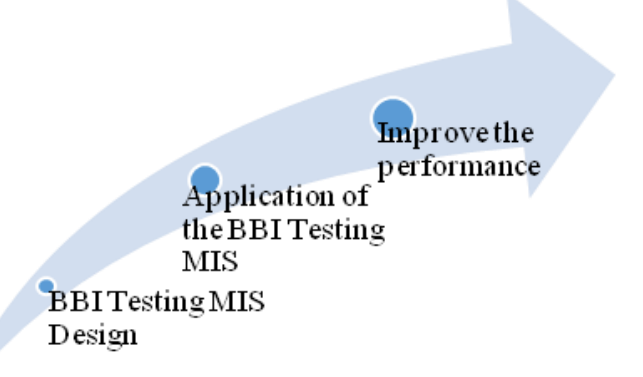

Fig 1. Design and Implementation of the BBI Testing MIS

As shown in the imageabove, at the Pengujan Fish Seed Center the management information system is currently running at the implementation stage and research is needed to assess whether the system has a significant impact on performance.

Formulation of the problem

1. Does the design of the management information system affect the performance of the Pengujan Fish Seed Center?

2. Does the application of the management information system affect the performance of the Pengujan Fish Seed Center?

3. Does the design and implementation of a management information system affect the performance of the Pengujan Fish Seed Center?

\subsection{Research purposes}

In accordance with the formulation of the problem, the objectives of this study are:

1. To research and analyze the design of management information system that affect the performance of the Pengujan Fish Seed Center.

2. To examine and analyze the effect of the application of management information systems on the performance of the Pengujan Fish Seed Center.

3. To examine and analyze the effect of the design and application of management information systems on the performance of the Pengujan Fish Seed Center.

\subsection{Research Benefits}

This research is expected to have both direct and indirect benefits in education.

1. Theoretical benefits

a) Contribute ideas for the management information system at the Pengujan Fish Seed Center in accordance with the demands of performance and in accordance with the needs of the development of management information systems.

b) Provide scientific contributions in the science of management information systems, namely making innovations in the use of applications in improving organizational capabilities.

c) As a foothold and reference for further research related to management information systems as well as a material for further study.

2. Practical benefits 
a) For the writers, itcan add insight and direct experience about management information systems that have been designed and implemented in an institution

b) For Pengujan Fish Seed Center, it is expected to gain hands-on experience on management information systems through design and implementation in order to improve.

\section{$2 \quad$ Methods}

\subsection{Time and place}

This research was carried out was at the Pengujan Fish Seed Center, Bintanfrom April to November 2021, a period of approximately 8 (eight) months.

\subsection{Materials and tools}

a) Tools

1. The computer that will implement the information management system software prototype

2. Questionnaire

3. SPSS Application (Software)

4. Camera for documentation

b) Material

1. Answered Questionnaire

2. Reports generated during use by BBI Testing

3. The results of the comparison and observation of BBI Pengujan who have implemented a management information system

\subsection{Data analysis}

a) Data Quality Test

1. A validity Test is used to measure the validity of a questionnaire. A questionnaire is said to be valid if the questions on the questionnaire are able to reveal something that will be measured by the questionnaire (Ghozali, 2016: 52).

2. A reliability Test is a tool to measure whether a questionnaire is an indicator of a variable or construct. A questionnaire is said to be reliable if a person's answer to a statement is consistent or stable from time to time (Ghozali, 2016: 47).

b) Classical Assumption

1. When using multiple regression equations, the classical assumption test is required. The Normality Test aims to test whether in the regression model the confounding or residual variables have a normal distribution. The $\mathrm{T}$ and $\mathrm{F}$ tests assume that the residual value follows a normal distribution

2. The multicollinearity testtests whether the regression model found a correlation between the independent variables i.e. to detect the presence or absence of multicollinearity in the regression. 
3. The Heteroscedasticity test aims to test whether in the regression model there is an inequality of variables from the residual of one observation to another observation

c) Hypothesis Test

1. Partial Test (T Test)

According to Ghozali (2016: 97) the T statistical test shows the influence of one explanatory/independent variable individually in explaining the variation of the dependent variable. The criteria for the significance of individual parameters $(t$ statistical test) are:

1) If the significance $>0.05$ then $\mathrm{H} 0$ is accepted

2) If the significance is $<0.05$ then $\mathrm{H} 0$ is rejected

2. Simultaneously (Test F)

The $\mathrm{F}$ test is a test of the significance of the equation used to determine how much influence the independent variables (X1, X2, X3) have together on the dependent variable (Y) By making the following decisions:

1) By comparing the calculated $F$ value with $F$ table If $F$ table $>F$ count, then $H 0$ is accepted and $\mathrm{H} 1$ is rejected If F table < F count, then $\mathrm{H} 0$ is rejected and $\mathrm{H} 1$ is accepted

2) By using the probability number of significance, if the number of significance probability $>0,05$; then $\mathrm{H} 0$ is accepted and $\mathrm{H} 1$ is rejected. If the number of significance probability $<0,05$; then $\mathrm{H} 0$ is rejected and $\mathrm{H} 1$ is accepted.

d) Coefficient of Determination (Adjusted R2)

According to Ghozali (2016: 95) the coefficient of determination (R2) measures the model's ability to explain variations in the dependent variable. The value of the coefficient of determination is zero and one. A small value of R2 means that the ability of the independent variables to explain the dependent variable is very clear. A value close to one means that the independent variables provide almost all the information needed to predict the dependent variable. The weakness of using the coefficient of determination is that it can affect the number of independent variables included in the model. For every additional independent variable, R2 must increasewhetheror not the variable has a significant effect on the dependent variable. Therefore, this study uses adjusted R2 when evaluating which regression model is the best. Unlike R2, the value of adjusted R2 can fluctuate if one independent variable is added to the model.

\section{$4 \quad$ Results and Discussion}

Demographics of Respondents. From a total of 31 respondents, 28 were male and three were female.

Table 1 Characteristics of Respondents by Gender

\begin{tabular}{rlrrrr}
\hline & & Frequency & Percent & Valid Percent & $\begin{array}{c}\text { Cumulative } \\
\text { Percent }\end{array}$ \\
\hline Valid & 1 & 28 & 90.3 & 90.3 & 90.3 \\
& 2 & 3 & 9.7 & 9.7 & 100.0 \\
& Total & 31 & 100.0 & 100.0 & \\
\hline
\end{tabular}


Table 2. Characteristics of Respondents Based on Age

\begin{tabular}{rrrrrr}
\hline & Frequency & Percent & Valid Percent & $\begin{array}{c}\text { Cumulative } \\
\text { Percent }\end{array}$ \\
\hline Valid & & & & 32.3 \\
& 20-30 Age & 10 & 32.3 & 32.3 & 80.6 \\
& 31-40 Age & 15 & 48.4 & 48.4 & 96.8 \\
& 41-50 Age & 5 & 16.1 & 16.1 & 100.0 \\
& $51-58$ Age & 1 & 3.2 & 3.2 & \\
\hline & Total & 31 & 100.0 & 100.0 & \\
\hline
\end{tabular}

Data Quality Test

Design Validity Test

Table 3. Design Variable Validity Results

\begin{tabular}{|c|c|c|}
\hline Question & R Count & Information \\
\hline $\mathrm{P} 1$ & 0,907 & Valid \\
\hline $\mathrm{P} 2$ & 0,919 & Valid \\
\hline P3 & 0,893 & Valid \\
\hline P4 & 0,876 & Valid \\
\hline P5 & 0,577 & Valid \\
\hline
\end{tabular}

Application Validity Test

Table 4 Application Variable Validity Results

\begin{tabular}{|c|c|c|}
\hline Question & R Count & Information \\
\hline $\mathrm{P} 1$ & 0,710 & Valid \\
\hline $\mathrm{P} 2$ & 0,883 & Valid \\
\hline P3 & 0,801 & Valid \\
\hline P4 & 0,662 & Valid \\
\hline P5 & 0,445 & Valid \\
\hline
\end{tabular}

Performance Validity Test

Table 5. Performance Variable Validity Results

\begin{tabular}{|c|c|c|}
\hline Question & R Count & Information \\
\hline K1 & 0,581 & Valid \\
\hline $\mathrm{K} 2$ & 0,506 & Valid \\
\hline K3 & 0,765 & Valid \\
\hline K4 & 0,704 & Valid \\
\hline K5 & 0,726 & Valid \\
\hline
\end{tabular}


The validity tests show that the questions in the questionnaire have valid criteria for all statement items based on Table $r$, rcount $>0.355$ then the validity test is valid, because $r$ count is greater than $r$ Table and valid instrument items will be used in the study,

Reliability Test Results

Table 6. Reliability test results

\begin{tabular}{llcl}
\hline No & Variables & Cronbach's Alpha & Information \\
\hline 1 & Design & 0,892 & Reliable \\
2 & Implementation & 0,718 & Reliable \\
3 & Performance & 0,765 & Reliable \\
\hline
\end{tabular}

Based on table above, all research variables are reliable and can be used in research.This is because the variables of Design, Implementation and Performance have an alpha coefficient of more than Cronbach's Alpha $>0.60$.

Classical Assumption Test

Normality Test Results

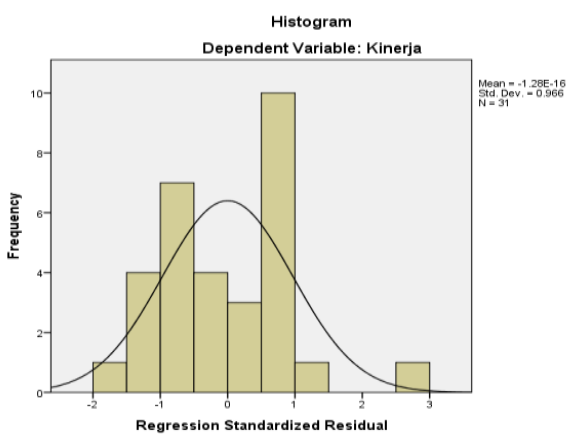

Fig. 4. Histogram Graph Results Normal P-P Plot of Regression Standardized Residual

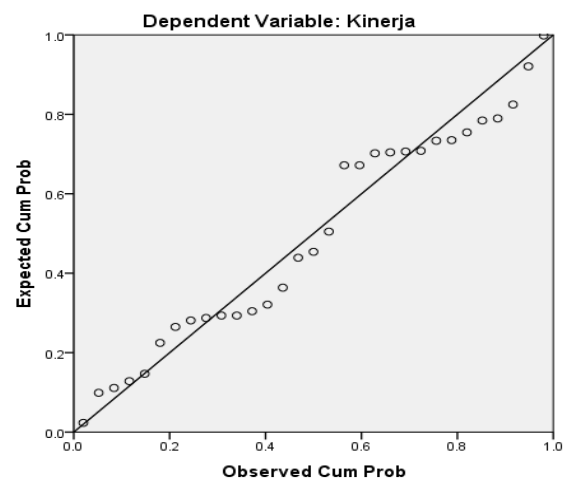

Fig.5. P-Plot Graph Results 
The histogram graph,Figure 4, shows a normal curve line, so it can be concluded that the data studied isnormally distributed.Figure 5 shows that all data isnormally distributed; the data distribution is around the diagonal line and follows the direction of the diagonal line.

Multicollinearity Test Results

Table 7. Multicollinearity Test Results

\begin{tabular}{|c|c|c|c|c|}
\hline \multicolumn{5}{|c|}{ Coefficients $^{\mathrm{a}}$} \\
\hline \multirow{2}{*}{\multicolumn{2}{|c|}{ Model }} & & & \\
\hline & & B & Tolerance & VIF \\
\hline \multirow[t]{3}{*}{1} & (Constant) & 8.574 & & \\
\hline & Design & .396 & .756 & 1.323 \\
\hline & Aplication & .247 & .756 & 1.323 \\
\hline
\end{tabular}

a. Dependent Variable: Performance

Table 7 above shows that the calculation results havea tolerance value of the independent variable of $>0.10$ and the calculation results of the VIF value also show that the independent variable has a VIF value $<10$. It can be concluded that there is no multicollinearity between the independent variables in the regression model.

Heteroscedasticity Test Results

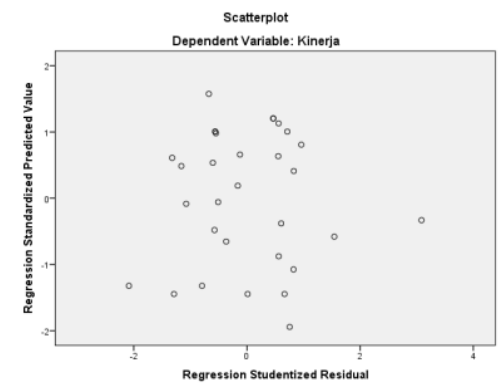

Fig.6. Heteroscedasticity Test Result

It can be seen in Figure 6 that the points are spread randomlyboth above and below the number 0 (zero) on the $\mathrm{Y}$ axis., not forming a clear pattern It can be concluded that there is no heteroscedasticity.

Multiple Linear Regression Analysis Test

Table 8. Multiple Linear Regression Analysis Test Results

\begin{tabular}{|c|c|c|c|c|}
\hline \multicolumn{2}{|c|}{ Model } & \multicolumn{2}{|c|}{ Unstandardized Coefficients } & \multirow{2}{*}{$\begin{array}{l}\text { Standardized } \\
\text { Coefficients } \\
\text { Beta }\end{array}$} \\
\hline \multirow[t]{3}{*}{1} & (Constant) & $\begin{array}{l}\text { B } \\
8.574\end{array}$ & $\begin{array}{l}\text { Std. Error } \\
1.871\end{array}$ & \\
\hline & Design & .396 & .094 & .568 \\
\hline & Aplication & .247 & .100 & .332 \\
\hline
\end{tabular}


a. Dependent Variable: Performance

Based on Table 8 above, multiple linear regression equations can be arranged and interpreted as follows:

Performance $=8.574+0.396$ Design $(X 1)+0.247$ Aplication $(X 2)+e$

1. The value of constant (a) is 8,574 , meaning that if the value of the Design and Aplication variable is considered non-existent or equal to 0 , then the Performance value is equal to 8,547

2. The regression coefficient value of the Design variable is 0.396. The Design value indicates a unidirectional relationship between the Performance and Design variables, which means that if the Design increases by 1 (one) point, then the Performance will increase by 0.396 with the assumption that the other independent variables remain.

3. The value of the regression coefficient of the application variable is 0.247 .Theaplication value shows a unidirectional relationship between the performance variable and the aplication, which means that if the aplication increases by 1 (one) point, then the performance will increase by 0.247 with the assumption that the other independent variables are constant.

4. Error

Hypothesis Testing

Statistical t Test Results

Table 9. Statistical t Test Results

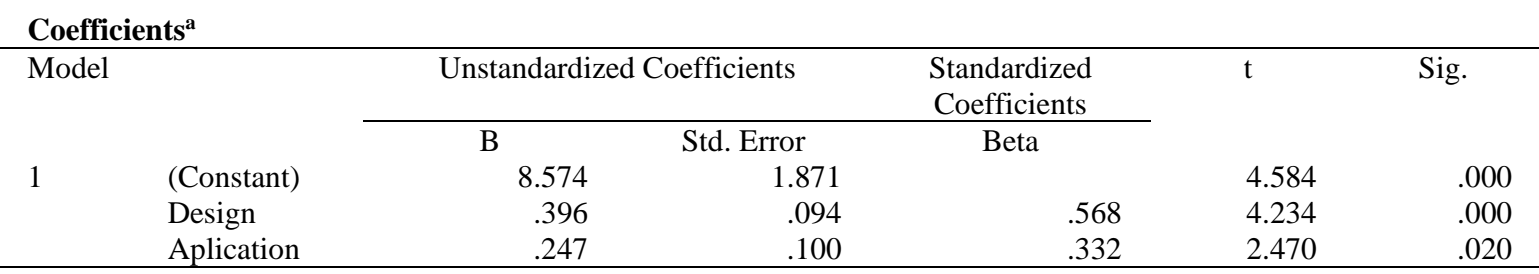

a. Dependent Variable: Performance

Hypothesis 1: The Effect of Design on Performance

Design variable with significance value 0.000 and tcount 4.234 . This means that the significance value is smaller than the 0.05 significance level $(<0.05)$. Based on the comparison of the tcount with tTable it was found that tcount $>$ tTable $(4.234>1.695)$. H1 is accepted and H0 is rejected; Design (X1) has a partially significant effect on Performance (Y).

Hypothesis 2: The Effect of Application on Performance

Implementationvariable with significance value 0.020 and tcount 2.470 . This means that the significance value is greater than the significance level of $0.05(>0.05)$. Based on the comparison of tcount with tTable, it was found that tcount $>$ tTable $(2,470>1,695)$. H2 is 
rejected and $\mathrm{H} 0$ is accepted;the application (X2) has a partially significant effect on performance $(\mathrm{Y})$.

Hypothesis 3: Simultaneous Design and Implementation Affects Performance Statistical F Test Results

Table 10. Statistical F Test Results

\begin{tabular}{|c|c|c|c|c|c|c|}
\hline \multirow[b]{2}{*}{ Model } & & \multicolumn{3}{|c|}{ ANOVA $^{a}$} & \multirow[b]{2}{*}{$\mathrm{F}$} & \multirow[b]{2}{*}{ Sig. } \\
\hline & & Sum of Squares & df & Mean Square & & \\
\hline 1 & Regression & 119.743 & 2 & 59.872 & 22.734 & $.000^{\mathrm{b}}$ \\
\hline & Residual & 73.741 & 28 & 2.634 & & \\
\hline - & Total & 193.484 & 30 & & & \\
\hline
\end{tabular}

Based on Table 10, it can be concluded that the significance value is 0.000 and the calculated $F$ value is 22.734. This means that the significance value is less than $0.05(0.000<0.05)$. Based on the comparison of Fcount with FTable (FTable $=0.05, \mathrm{df}=31$ ) it is foundthat the Fcount is 22,734 which is greater than FTable, which is $3.30(22.734>3.30)$. H3 is accepted and $\mathrm{HO}$ is rejected;that is the design and implementation simultaneouslyhave a significant effect on performance.

Coefficient of Determination Testing (R2)

Table 11. The Result of the Coefficient of Determination

\begin{tabular}{|c|c|c|c|c|c|}
\hline \multicolumn{6}{|c|}{ Model Summary ${ }^{b}$} \\
\hline Model & $\mathrm{R}$ & R Square & $\begin{array}{c}\text { Adjusted R } \\
\text { Square }\end{array}$ & $\begin{array}{c}\text { Std. Error of the } \\
\text { Estimate }\end{array}$ & Durbin-Watson \\
\hline 1 & $.787^{\mathrm{a}}$ & .619 & .592 & 1.623 & 1.612 \\
\hline
\end{tabular}

Based on Table 11 above, it can be seen that the Adjusted R Square in this study is 0.592.This shows that $59.2 \%$ percentage of the influence of the independent variable, namely the design and implementation effects the performance at the Pengujan Fish Seed Center, while the remaining $41.8 \%$ is influenced or explained by other factors not included in this study.

\subsection{Hypothesis Discussion}

\subsubsection{Effect of Design on Performance}

A production system that has been designed to speed up manual work in order to speed up work, as technology advances. This increasingly rapid information will affect various aspects of human life. The perceived impact is that humans will continue to think and develop this technology as a unitary tool. System components or system elements can be in the form of a subsystem or parts of the system so that the design of information systems must be developed for the convenience and efficiency of a job. 
The design that has been carried out at the Pengujan Fish Seed Center is a new system or improving an existing system so that the system becomes better and usually this process consists of designing input, output and files. So that when the system is used it can provide an overview of the data that has been inputted so as to produce and facilitate reports for decision making for management. The finding of this research is in line with the research conducted by Meliala (2011).

\subsubsection{Effect of Aplication Performance}

The application in question is implementing a database or application that has been created in order to achieve performance for the Pengujan Fish Seed Center in terms of inputting or processing fish hatchery data so that the role becomes easier and more reliableas it is not recorded manually but through computerization whichensures that the data will be collected. This will generate an updated report and it will not be possible for double input to occur. With the implementation of the database application, it will no longer be difficult to provide reports that aresystematically arranged and valid to those who require them. , These results are in line with research conducted by ArifJurachman. (2018) Hertanto, Domai and Amin (2016) stated that the application of a management information system found thatthe Sidoarjo Regency Government employees were more effective and efficient in their daily performance. So the application has a positive and significant impact on performance.

\subsubsection{Effect of Design and Aplicationon Performance}

Based on the results of data analysis and the discussion that has been carried out by the author, it can be concluded that among the independent variables, Design (X1), and pplication (X2) have the most dominant influence on Performance at the Pengujan Fish Seed Center.Design hasa tcount value of 4.234 and a probability of sig. : 0.000 . Therefore, design is the most dominant variable affecting performance and enables aninformation management system to provide information efficiently because the data entered into the database is realandupdated in accordance with existing reality and produces valid reports so thatit is efficient and effective. on the performance that has been done

\section{References}

[1] Laudon, Kenneth \& P. Laudon, Jane. 2005.Sistem Informasi Manajemen Mengelola Perusahaan Digital. Edisi 8.Andi Offset. Yogyakarta.

[2] Ghozali, Imam. 2016. Aplikasi Analisis Multivariete Dengan Program IBM SPSS 23 (Edisi 8). Cetakan ke VIII. Semarang :BadanPenerbit Universitas Diponegoro.

[3] J. W. Satzinger, R. B. Jackson and S. D. Burd. 2011. Systems Analysis and Design in a Changing World, Sixth ed. Course Technology. Boston, MA

[4] Mangkuprawira.S dan Aida V.Hubeis. 2007. Manajemen Mutu Sumber Daya Manusia. Ghalia Indonesia.Bogor.

[5] Nafisah,Syifaun, 2003, Pengertian Perancangan, available tohttp://rumohkuta.blogspot.com/2013/02/pengertian-perancangan.html,diakses pada 5 maret 2021 pukul 11.00 WIB

[6] O’Brien \&Marakas. 2009. Management Information Systems.Ninth Edition. New York:

[7] Rivai, Veithzal. 2012. Manajemen Sumber Daya Manusia Untuk Perusahaan. Jakarta: 
Raja GrafindoPersada.

[8] Simanjuntak P. 2010. Manajemen Hubungan Industrial. Pustaka Sinar Harapan. Jakarta [9] Sugiyono 2015. Metode Penelitian Kombinasi (Mix Methods). Alfabeta. Bandung

[10] Wirawan. 2009. Evaluasi Kinerja Sumber Daya Manusia Teori Aplikasi dan Penelitian. Penerbit: SalembaEmpat. Jakarta. 